\title{
SOME ASPECTS OF IMPLEMENTING THE RIGHT TO THE FREE OF CHARGE SECONDARY LEGAL AID IN THE CONTEXT OF ACCESS TO JUSTICE
}

The article is devoted to the analysis of certain provisions of the current legislation of Ukraine concerning the understanding and interpretation of the accessibility of justice as a key guarantee of ensuring the implementation of international norms and provisions of domestic legislation. The link between the principle of access to justice and the mechanism for providing free secondary legal aid has been followed. The procedure for the provision of secondary legal aid free of charge, the problematic issues that arise in the process of providing such assistance and the further prospects for solving these problems are also defined. The categories of persons entitled to free secondary legal aid are characterized, certain problem aspects of their administrative-legal status are identified, which create obstacles in the practical realization of the right to free secondary legal aid. A number of legislative amendments to the State Fundamental Law, procedural acts, which significantly influenced the realization of the right to secondary free legal aid, were considered. The jurisprudence of the European Court of Human Rights and the practice of domestic courts regarding access to justice are analyzed. The statistical data of the Coordination Center on the provision of free secondary legal aid as an indicator of ensuring access to justice for vulnerable categories of people in Ukraine is researched. The international community recognizes that the right to a fair trial includes the guarantees of procedural rights, namely: the right to access to a court, the right to execute court decisions and the right to the final judgment. In Ukraine, free legal aid can be considered as a mechanism to ensure compliance with international obligations undertaken by our state. The article notes that access to justice is not only the territorial approximation of the organs of justice to citizens, but also the existence of real rights and opportunities for their implementation by appealing to the court, initiating court proceedings, as well as the presence of correspondent duties of the subjects conducting judicial proceedings the process, which in general, meets the requirements stipulated in international legal acts. The article also examines the impact of the judicial reform carried out on the provision of secondary free-of-charge assistance in Ukraine, and, accordingly, the impact on access to justice in connection with the introduction of the so-called "monopoly of advocates" in court.

Key words: free secondary legal aid, access to justice, judicial reform, European Court of Human Rights. 


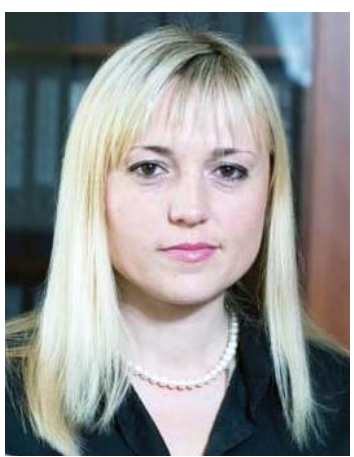

Nataliia Shesternina, Deputy Director Sumy Local Center Provision of Free Secondary Legal Aid

sh.natalia22@ukr.net

\section{Introduction}

Ukraine's aspiration to become a full member of the international and European community, determine the directions of its activities and the vector of its commitments. In this context, the issue of access to justice and access to free secondary legal aid to vulnerable categories of citizens is becoming an important consideration. Referring to the content of international norms, in particular the European Convention for the Protection of Human Rights and Fundamental Freedoms, the accessibility of justice (access to justice) is one of the key guarantees of the right to redress, at the level with such criteria as justice, completeness, legality, impartiality of the court.

The urgency of this topic is due to the needs of optimization of the institute of free legal aid for vulnerable categories of citizens and improvement of the institute of judicial protection of rights and legitimate interests of man and citizen, as well as the lack research of scientific on this topic. Separate ones scholars investigated institute of the free legal aid, the quality of its provision (in particular: Y.Ya. Buryak, O.M. Dufenyuk, S.I. Marko, S.V. Overchuk, etc.). A lot of attention was devoted today to the issues of judicial reform (O.M. Ovcharenko, M.V. Rudenko, etc.). However, the impact of the reform on the accessibility of justice and the adequate level of provision of free secondary legal aid in the context of this is not sufficiently investigated. Practical problems of realization of the right to access to justice lead to the need for a thorough study of this topic.

The purpose and tasks of this study is to address the problematic issues of the availability of justice in Ukraine to vulnerable categories of citizens, within the framework realization of the right to free of charge secondary legal aid.

The judicial reform of recent years conducted in Ukraine requires a detailed analysis of the provision and observance of the rights of vulnerable citizens, in particular, the impact of the abovementioned reform on the provision of rights of this category of citizens, in particular the right to protection guaranteed by the Constitution, including the judicial one. The purpose of the judicial reform was proclaimed to provide an independent, independent judicial branch of power capable of protecting the rights, freedoms and legitimate interests of man and citizen, the state, society as a whole. The reform is inextricably linked with the activities of centers for providing free legal assistance in providing access to justice and protecting the rights and legitimate interests of citizens, 
foreigners, stateless persons, refugees, etc. Therefore, from a practical point of view, it is urgently necessary to consider the issue of influence judicial reform on the state of ensuring the rights and freedoms of citizens entitled to free legal assistance. The Institute of Free Legal Aid (both primary and secondary) is one of the indicators of a democratic, legal, social state. A number of international documents emphasize that free legal aid is not an act of charity, but a state duty. S.V. Goncharenko, investigating the facts of the historical formation and development of the institute of free legal aid, draws attention to the fact that in historical sources and legal literature you can find information about the attitude, in different historical periods and in different countries, the institute of providing legal assistance to vulnerable strata people. Based on this, the author concludes that the lawyer community carries out the care of people belonging to the categories of the poor, the sick, the old, who independently can not protect their rights and need professional protection and legal counseling. But the state in these cases did not usually stand aside. When the advocacy community lost a feeling of reality about the financial capabilities of its fellow citizens, and proved to be unable to independently perform its natural function effectively, intervention by the legislator, as a rule, became inevitable (Honcharenko, 2011).

\section{International and national legal regulation}

Today, such intervention is carried out by the state through legal regulation of the institute of free legal aid. Within the framework of Ukraine's international commitments, it is worth paying attention to the ratification of its Basic Provisions on the role of lawyers adopted by the 8th UN Congress in 1990, according to which the Government's duty is to provide an effective procedure and working mechanism for real and equal access to lawyers all persons residing in its territory and subject to its jurisdiction, regardless of race, color, ethnic origin, sex, language, religion, political or other opinion, national or social origin, econominal or other status.

And also the obligation to provide the necessary funding and other resources for legal assistance to the poor and other indigent people. Professional associations of lawyers should cooperate in organizing and creating conditions for such assistance (Basic provisions on the role of lawyers, 1990). In addition, Resolution No. (78)8 of the Committee of Ministers on Legal Assistance and Consultation dated 02.03.1978 recognized that the right to access to justice and fair trial are a key feature of a democratic society. The state is obliged to take all necessary measures to eliminate economic obstacles to access to justice and that the availability of appropriate legal aid systems will facilitate the fulfillment of this task, especially for those who are in an economically disadvantaged position. No one shall be deprived of the possibility of using or defending his rights in any courts, owing to the impediments of an economic nature. To this end, any person should have the right to the necessary legal assistance in the trial (Resolution No. $(78) 8,1978)$. The resolution also stresses the need for professional assistance. Today, this is due to the introduction of the concept of "professional legal assistance", the content of which, in accordance with Article 15 of the Civil Procedural Code of Ukraine, "is that representation in court as a form of legal assistance is carried out exclusively by a lawyer" (The Civil Procedural Code of Ukraine, 2004). Such a provision is sufficiently reasoned, since the quality of legal assistance is an important indicator of the effectiveness of 
ensuring access to justice, and not just its declaration. The constitutional guarantees of the availability of justice in Ukraine are the fixing of the provision that "the rights and freedoms of man and citizen are protected by the court" (Article 55 of the Constitution of Ukraine, 1996) and the spreading of jurisdiction of the courts to "any legal disputes and any criminal charge" (Article 124 of the Constitution of Ukraine, 1996). References to these norms are also contained in the content of part 3 of Article 7 of the Law of Ukraine "On the Judiciary and Status of Judges", which provides that "the accessibility of justice for each person shall be ensured in accordance with the Constitution of Ukraine and in accordance with the procedure established by the laws of Ukraine" (On the Judiciary and Status of Judges, 2016). In addition, these guarantees are provided by the Decree of the President of Ukraine "On the Strategy for the reform of the judicial system, judiciary and related legal institutions for 2015-2020" dated May 20, 2015, No. 276/2015 (On the Strategy for the reform of the judicial system, judiciary and related legal institutions for 2015-2020,2015). Among the main areas of implementation of this strategy is "strengthening the guarantees of the implementation of lawyer activities and ensuring the availability of free legal aid". The strategy provides for measures that should ensure the implementation of this direction of reform: in the short term defining the types of legal aid that can only be carried out by a lawyer, which will enable to improve the quality of legal assistance and the quality of the administration of justice as a whole, while not limiting the participants in the legal process in law on access to justice; facilitating access of citizens to free legal aid through improved quality standards for providing legal aid and their compliance; expanding the possibility of providing primary and secondary free legal aid in civil and administrative cases, including in regions, at a higher level; provision of proper financing of the system of provision of free legal aid both from the state budget and from private sources. That is, modern judicial reform in Ukraine has finally the most extensive and comprehensive effect, since its complex nature involves reforming both the judicial system itself and related interrelated institutions, including free legal aid.

Yu.I. Matat, draws attention to the fact that, taking into account the mandatory application of the European Court of Human Rights practice, "access to justice in accordance with the standards of the European Court of Human Rights means the ability of an individual to freely receive judicial protection as access to an independent and impartial settlement of disputes in accordance with the established procedure on the basis of the rule of law. The category under consideration together with elements such as the final decision of the court and the timely execution of final decisions are integral parts of the right to a court, which, in its turn, occupies one of the main places in the system of fundamental values of any democratic society" (Matat, 2016).

According to Art. 13 of the Convention for the Protection of Human Rights and Fundamental Freedoms, States Parties are required to provide an effective means of legal protection in the event of violation of the rights and freedoms recognized in the Convention. States decide, at their discretion, how they will fulfill this obligation, but effective remedies must be available, provide a means to recover damages, and provide reasonable prospects for successful prosecution. According to Art. 6 of the Convention, the right to a fair trial includes the guarantees of procedural rights, namely: the right to access to a 
court, the right to execute court decisions and the right to the final judgment (Convention for the Protection of Human Rights and Fundamental Freedoms, 1950). In Ukraine, free legal aid can be considered as a mechanism to ensure compliance with the requirements of the ratified Convention.

\section{Subjects of the right to free secondary legal aid}

Legal assistance is one of the key criteria for the accessibility of justice. All persons who are under the jurisdiction of our state are entitled to free primary legal aid. Regarding free secondary legal aid, the Law "On free legal aid" refers to certain categories of persons who are entitled to the following types of legal services: 1) protection; 2) the representation of the interests of persons entitled to free secondary legal aid in courts, other state bodies, bodies of local self-government, to other persons; 3) drafting of documents of a procedural nature. But not all individuals have the right to all three types of legal services. As noted by V.I. Formanyuk, only the law-defined circle of subjects has the right to take advantage of free secondary legal aid. In the opinion of the author, the legislator proceeded from the following considerations when determining the subjects that were granted the aforementioned right:

1) insolvent citizens;

2) those with certain privileges;

3) those belonging to those categories of persons for whom the law already has the right to free legal aid (Formanyuk, 2014).

The Law of Ukraine "On free legal aid" determines the following circle of persons who are subjects of the right to secondary free legal aid:

- persons under the jurisdiction of Ukraine if their average monthly income does not exceed two sizes of the subsistence minimum calculated and approved by law for persons belonging to the main social and demographic groups of the population as well as disabled persons who receive a pension or assistance that is appointed instead of a pension, at a rate not exceeding two subsistence minimum for the disabled;

- children, including orphans, children deprived of parental care, children in difficult living conditions, children who have suffered as a result of hostilities or armed conflict;

- internally displaced persons;

- persons in criminal proceedings in respect of which, in accordance with the provisions of the Criminal Procedure Code of Ukraine, a defender is appointed by an investigator, prosecutor, investigator, judge or court for the purpose of protection for the purpose or conduct of a separate procedural act, as well as persons sentenced to imprisonment, detention in disciplinary battalion of servicemen or restraint of liberty;

- persons covered by the Law of Ukraine "On Refugees and Persons in Need of Additional or Temporary Protection" from the moment the person submits an application for recognition as a refugee or a person who needs additional protection in Ukraine until the final decision on the application is made, as well as foreigners and stateless persons detained for the purpose of identification and enforcement of deportation from the time of detention;

- war veterans and persons covered by the Law of Ukraine "On the Status of War Veterans, Guarantees of Their Social Protection", persons who have special merits and special labor merits to the Motherland, persons belonging to the victims of Nazi persecution; 
- persons who have suffered from domestic violence or gender-based violence;

- persons who are detained in accordance with the provisions of the criminal procedural law;

- persons in respect of whom a preventive measure was taken in the form of detention;

- citizens of Ukraine who have applied for registration as internally displaced persons on issues related to obtaining a certificate on the registration of internally displaced persons;

- persons subject to administrative detention;

- persons to whom an administrative arrest has been applied;

- persons under the jurisdiction of Ukraine and applied for the status of a person covered by the Law of Ukraine "On the status of veterans of war, guarantees of their social protection";

- persons in respect of which the court is considering a case concerning limitation of civil capacity of an individual, recognition of a physical person incapacitated and resumption of civil capacity of an individual, during the consideration of a case in court;

- persons in respect of which the court is considering a case concerning the provision of psychiatric assistance in a compulsory manner, during the consideration of a case in court;

- persons rehabilitated in accordance with the legislation of Ukraine concerning issues related to rehabilitation (On free legal aid, 2011).

\section{The mechanism of providing free of charge secondary legal aid}

The Law "On free legal aid" provides for the appropriate mechanism for realization of the right to receive free secondary legal aid. First of all, the request for the provision of legal services in the framework of secondary legal aid (protection, representation of the interests of persons entitled to free secondary legal aid, in courts, other state bodies, local self-government bodies, to other persons, the drawing up of documents of a procedural nature) are submitted by persons who have reached the age of majority, and in cases concerning children, they are submitted by their legal representatives at the place of actual residence of the child or her legal representatives irrespective of the registration the place of residence or whereabouts of the person, in addition, in cases concerning persons recognized as incapacitated by the court or whose capacity is restricted by a court, they are submitted by their guardians or trustees at the place of actual residence of such persons or their guardians or guardians, regardless of the registration of the place of residence or place stay of the person, to the Center for the provision of free secondary legal aid or to the territorial justice authority at the place of actual residence of such persons, regardless of the registration of the place of residence or place stay of the person.

Along with the application for the provision of free secondary legal aid, the person or legal representative of the person must submit documents confirming the affiliation specified person to one of the vulnerable categories of persons provided for in part one of Article 14 of the Law "On free legal aid".

In the case of a person applying for one of the types of free legal aid provided for by applicable law, the Center for the provision of free secondary care shall within ten days 
from the date of receipt of such application decide on the granting (or refusal) of the free secondary legal aid.

If a person belongs to one of the categories of persons provided for in part one of Article 14 of the Law "On free legal aid", which is confirmed by the relevant documents, the Center for the provision of free secondary legal aid decides on the provision of free secondary legal aid and in writing informs the person or its a legal representative, as well as a court, a body of state power, a body of local self-government, in which the representation of the person's interests will be carried out.

In the event that the person has no grounds for obtaining free secondary legal aid, the Center for the provision of free secondary legal aid makes a decision to refuse to provide free secondary legal aid and sends a copy of this decision to the person who applied for such assistance at the same time as the explanation the procedure for appealing the decision to refuse to provide free secondary legal aid.

The list of reasons why a person may be denied the provision of free secondary legal aid is defined by the Law of Ukraine "On free legal aid", one of the following grounds is sufficient:

1) the person does not belong to any of the categories of persons provided for in part one of Article 14 of the Law "On free legal aid";

2) the person submitted false information or false documents for the purpose of assigning it to one category of persons who are entitled to free secondary legal aid;

3 ) the person's claims for the protection or restoration of his rights are unlawful;

4) the person was previously provided with free secondary legal aid on the same issue;

5) the person has used all national remedies in the case, for which he applies for the provision of free secondary legal aid.

In practice, the most frequent problems arise with the confirmation of the corresponding legal status of a person who is entitled to free secondary legal aid. Due to low awareness of citizens, there are many difficulties with the presentation of the required package of documents. In addition, the process of collecting the necessary documents is quite lengthy, this causes the difficulty in making decisions by the Center for the provision of free secondary legal aid.

According to the Coordination Center for the provision of legal aid, in total, in the current year, 54142 orders were issued for the provision of free secondary legal aid, of which the number of orders issued by the center to provide free secondary legal aid to persons subject to administrative detention is 3407 , to which the administrative arrest was applied - 828; the number of orders issued by the center for the provision of free secondary legal aid to persons who are detained in accordance with the provisions of the criminal procedural law - 12 043; the number of registered orders (decisions) for the protection by appointment - 27 699; the number of registered decisions (decisions) for the provision of free secondary legal aid in procedures related to extradition - 103 (Operational information, 2018). Such indicators for the provision of free secondary legal aid centers confirm the inextricable link between the institution of free secondary legal aid as an important mechanism for ensuring the availability of justice. It should be noted that access to justice is not only the territorial proximity of the justice system to citizens, but also the availability of rights and opportunities for their implementation by appealing 
to the court, initiating court proceedings, as well as the presence of correspondent duties of the subjects conducting the trial, which in general corresponds to the requirements stipulated in the international legal acts. According to the statistics of the ECHR in 2016, 79750 applications were filed with the ECHR, while the three leading countries are Ukraine $(22,8 \%)$, Turkey $(15,8 \%)$, Hungary $(11,2 \%)$. Consequently, Ukraine occupies a leading position among the countries that have ratified the Convention by the number of appeals to the ECHR, which in turn indicates that there are problems with the implementation of the rights provided for by the Convention, and therefore the study and implementation of the practice of the ECHR can positively affect the situation.

\section{Conclusions}

On the basis of the analysis, there is an inextricable link between primary and secondary free legal aid. In the framework of primary free assistance, the person receives consultations and clarifications regarding the legal status of the category of persons entitled to free secondary legal aid. Access to unpaid secondary legal aid depends on the quality of providing primary legal aid to a person in need. One of the debatable problems for today remains the problem of administration in the field of providing free secondary legal aid. Some scholars and practitioners do not agree with the mechanism for appointing a lawyer in the context of free secondary legal aid and the procedure for assessing the quality of the provision of such free of charge secondary legal aid. In this context, we emphasize that free secondary legal aid is, above all, a state guarantee, it is not an interference with advocacy, and in no way not load the institute of advocacy. The institute of free legal aid is an important guarantee of the state before a person. Judicial reform has had a significant impact on the provision of free secondary legal aid. Judicial reform has defined the concept of professional legal assistance, which according to the current legislation is provided only by advocates. The development of the system of free legal aid has become one of the areas of reform that continues to be implemented today. In this regard, Centers for the provision of free secondary legal aid, it is necessary to strengthen the cooperation of advocates to ensure the accessibility of justice for those entitled to free secondary legal aid. Future prospects for scientific and theoretical consideration are the issues of improving the mechanism of provision of free secondary legal aid among which the important role played by such indicators as quality, speed and accessibility. According to the practice of the European Court of Human Rights, access to justice should be considered as a real opportunity for a person to be free to obtain judicial protection. Free secondary legal aid is an important tool in ensuring such a possibility.

\section{Bibliography:}

1. Гончаренко С.В. Проблеми надання безоплатної правової допомоги. Короткий огляд новітніх тенденцій. Адвокат. 2011. № 11. С. 12-16.

2. Конвенція про захист прав людини і основоположних свобод: міжнародний документ від 4 листопада 1950 р. (ратифікована Законом України № 475/97-ВР від 17 липня 1997 р.) / Верховна Рада України. URL: http://zakon2.rada.gov.ua/laws/show/995_004.

3. Конституція України: Закон України від 28 червня 1996 р. № 254к/96-ВР / Верховна Рада України. Відомості Верховної Ради України. 1996. № 30. Ст. 141.

4. Матат Ю.І. Право на доступ до правосуддя: європейський досвід та проблеми забезпечення в Україні. URL: http://www.legalactivity.com.ua/index.php?option=com_content\&vie $\mathrm{w}=$ article\&id=1419\%3A081216-22\&catid=171\%3A6-1216\&Itemid=212\&lang $=$ ru. 
5. Оперативна інформація по Регіональним центрам 2018 рік / Координаційний центр 3 надання правової допомоги. URL: http://legalaid.gov.ua/ua/statystychni-dani/2175-rehionalnitsentry-2018.

6. Основні положення про роль адвокатів: міжнародний документ, прийнятий VIII Конгресом ООН 1 серпня 1990 р. / Конгрес Організації Об’єднаних Націй. URL: http://zakon5.rada.gov.ua/laws/show/995_835.

7. Про безоплатну правову допомогу: Закон України від 2 червня 2011 р. № 3460-VI / Верховна Рада України. Відомості Верховної Ради України. 2011. № 51. Ст. 577.

8. Про Стратегію реформування судоустрою, судочинства та суміжних правових інститутів на 2015-2020 роки: Указ Президента України від 20 травня 2015 р. № 276/2015 / Президент України. URL: http://zakon.rada.gov.ua/laws/show/276/2015.

9. Про судоустрій і статус суддів: Закон України від 2 червня 2016 р. № 1402-VIII / Верховна Рада України. Відомості Верховної Ради України. 2016. № 31. Ст. 545.

10. Резолюція № 78(8) Комітету міністрів про юридичну допомогу та консультації: міжнародний документ від 2 березня 1978 р. / Комітет міністрів Ради Європи. URL: http://zakon2.rada.gov.ua/laws/show/994_132.

11. Форманюк В.І. Надання безоплатної вторинної правової допомоги в Україні. Науковий вісник Ужгородського національного університету. Серія «Право». 2014. Вип. 29. Ч. 2. C. $32-35$.

12. Цивільний процесуальний кодекс України: Закон України від 18 березня 2004 р. № 1618-IV / Верховна Рада України. Відомості Верховної Ради України. 2004. № 40-42. Ст. 492.

\section{References:}

1. Honcharenko, S.V. (2011). Problemy nadannia bezoplatnoi pravovoi dopomohy. Korotkyi ohliad novitnikh tendentsii [Problems of granting legal aid. A brief overview of the latest trends]. Advokat, no. 11, pp. 12-16.

2. Verkhovna Rada of Ukraine (1950). Konventsiia pro zakhyst prav liudyny i osnovopolozhnykh svobod: mizhnarodnyi document [Convention for the Protection of Human Rights and Fundamental Freedoms: an international instrument]. Retrieved from: http://zakon2. rada.gov.ua/laws/show/995_004.

3. Verkhovna Rada of Ukraine (1996). Konstytutsiia Ukrainy: Zakon Ukrainy [The Constitution of Ukraine: The Law of Ukraine]. Vidomosti Verkhovnoi Rady Ukrainy, no. 30, art. 141.

4. Matat, Yu.I. (2016). Pravo na dostup do pravosuddia: yevropeiskyi dosvid ta problemy zabezpechennia v Ukraini [The right to access to justice: European experience and problems in Ukraine]. Retrieved from: http://www.legalactivity.com.ua/index.php?option=com_content\&vie $\mathrm{w}=$ article\&id=1419\%3A081216-22\&catid=171\%3A6-1216\&Itemid=212\&lang=ru.

5. Coordination Center for Legal Aid (2018). Operatyvna informatsiia po Rehionalnym tsentram 2018 rik [Operational information for Regional Centers 2018]. Retrieved from: http://legalaid.gov.ua/ua/statystychni-dani/2175-rehionalni-tsentry-2018.

6. United Nations Congress (1990). Osnovni polozhennia pro rol advokativ: mizhnarodnyi document [Basic provisions on the role of lawyers: an international document]. Retrieved from: http://zakon5.rada.gov.ua/laws/show/995_835.

7. Verkhovna Rada of Ukraine (2011). Pro bezoplatnu pravovu dopomohu: Zakon Ukrainy [About Free Legal Aid: The Law of Ukraine]. Vidomosti Verkhovnoi Rady Ukrainy, no. 51, art. 577. 
8. President of Ukraine (2015). Pro Stratehiiu reformuvannia sudoustroiu, sudochynstva ta sumizhnykh pravovykh instytutiv na 2015-2020 roky: Ukaz [On the Strategy for the Reform of the Judiciary, the Judiciary and Related Legal Institutions for 2015-2020: Decree]. Retrieved from: http://zakon.rada.gov.ua/laws/show/276/2015.

9. Verkhovna Rada of Ukraine (2016). Pro sudoustrii i status suddiv: Zakon Ukrainy [On Judicial System and Status of Judges: The Law of Ukraine]. Vidomosti Verkhovnoi Rady Ukrainy, no. 31 , art. 545 .

10. Committee of Ministers of the Council of Europe (1978). Rezoliutsiia № 78(8) Komitetu ministriv pro yurydychnu dopomohu ta konsultatsii: mizhnarodnyi document [Resolution No. 78(8) of the Committee of Ministers on Legal Assistance and Consultation: an international instrument]. Retrieved from: http://zakon2.rada.gov.ua/laws/show/994_132.

11. Formaniuk, V.I. (2014). Nadannia bezoplatnoi vtorynnoi pravovoi dopomohy v Ukraini [Granting of free secondary legal aid in Ukraine]. Naukovyi visnyk Uzhhorodskoho natsionalnoho universytetu. Seriia "Pravo", iss. 29, part 2, pp. 32-35.

12. Verkhovna Rada of Ukraine (2004). Tsyvilnyi protsesualnyi kodeks Ukrainy: Zakon Ukrainy [Civil Procedural Code of Ukraine: Law of Ukraine]. Vidomosti Verkhovnoi Rady Ukrainy, no. 40-42, art. 492.

\title{
ОКРЕМІ АСПЕКТИ РЕАЛІЗАЦІЇ ПРАВА НА БЕЗОПЛАТНУ ВТОРИННУ ПРАВОВУ ДОПОМОГУ В КОНТЕКСТІ ДОСТУПНОСТІ ПРАВОСУДДЯ
}

\author{
Шестерніна Наталія Петрівна, \\ заступник директора \\ Сумського місцевого центру з надання безоплатної вторинної правової допомоги \\ sh.natalia22@ukr.net
}

Статтю присвячено аналізу окремих положень законодавства України та практики Європейського суду з прав людини стосовно надання безоплатної вторинної правової допомоги в Україні в контексті адміністративно-правового статусу осіб, які мають право на отримання такої допомоги, процедури ї̈ надання, проблемних питань, щзо виникають у прочесі надання такої допомоги. Проведено аналіз законодавчих змін, внесених до Конституції України та процесуальних актів, щзо значним чином вплинуло на реалізацію права на вторинну безоплатну правову допомогу. Простежено вплив судової реформи, проведеної в Україні, на забезпечення доступності громадян до правосуддя. Оскільки право на захист своїх прав є основоположною гарантією, визнаною й закріпленою Конституиією Украӥни, будь-яка реформа, проведена в державі, має відповідати змісту зазначеного конституційного принципу. Утвердження прав і свобод людини й громадянина є головним обов'язком правової держави.

Ключові слова: безоплатна вторинна правова допомога, доступність правосуддя, судова реформа, Європейський суд з прав людини. 